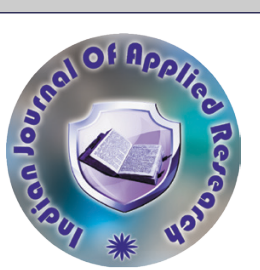

Anesthesiology

ENVIRONMENTAL PROTECTION AND ROLE OF WOMEN IN RURAL SOCIETY

\title{
Dr. Rukimani*
}

Corresponding Author

\section{KEYWORDS :}

In the research paper presented, women have not found the real place of women in our country and society. Without these age-old traditions and evils, women cannot cope with it, and they will remain trapped in the same old customs and occultism, which is why women cannot take decisions free from all restrictions. We have to change their thinking towards ourselves.

It is also written in our texts, "Yatra Narmastu Pujyate, Ramante Tatra Devta". The God reside where the woman is worshiped.

In our country, women are facing many problems, such as Dowry. This is a practice that has been in place since ancient times. Boys ask for dowry without any fear, we all should end the dowry system. Women should be given a chance to choose anyone according to their rights.

In our country, women do not have the right to roam freely, because some bad people have to live in fear.

Women are more positive to please God than men, they have more faith in God. Therefore, we can say that women are more traditional than men.

Religious discourses, rituals, gatherings, etc. should be organized in the rural society, so that the atmosphere of the rural environment is kept pure, holy and spiritual. By doing this, there is a good effect in people's mind and brain.

First of all we look at our culture and look at the social practices and customs, it is found that since ancient times women have been environmentally conscious, the direct example of which is still observed by women on the occasion of fasting festival or just throughout the day. Involve and worship many trees like Peepal, Tulsi, Amla, Ashoka, Bell, Neem etc. Trees and many virtues and various animals like cow, bull, rat, horse, snake, monkey, owl etc. Providing protection through Archana is seen.

In this way, the concept of protection against not only trees, plants but also animals and birds has existed since ancient times. Not only this, the feeling of protection towards water sources has been prevalent in women since ancient times. Such as worshiping Ganga, worshiping wells or worshiping the pond.

It is thus clear that women have always been at the forefront of keeping the entire ecology balanced. This feeling of nature conservation or environmental protection by women settled in our Indian culture has been passed down from generation to generation and is still seen today.

Here one thing is clear that in India's social structure where men are many times more important and convenient than women, especially in rural areas. Environmental pollution has severely affected the lifestyle of women, that is why these rural women are more conscious of environmental protection because of their direct contact with environment and nature.

Today, blind trees are being cut in such areas, women have to go many kilometers to collect wood for burning.

Similarly, where there is scarcity of water, especially in the desert areas, hilly and mountainous areas, the responsibility of women is to raise water, and one has to walk 10-15 kilometers for 1 pot of water.

It is thus clear that women have a direct and deep connection with natural resources such as forests, soil and water. This is the reason why women are considered to be its guardians, especially among tribal people, the economy of forest wealth is considered to be solely of women. This is the reason why the participation of women in environmental protection, especially forest protection, has become extremely important and women are also aware of it.

The Chipko movement, which has established its identity in the mountainous regions of India, has created a new consciousness towards environmental protection, especially forest protection. This movement is entirely related to women. This movement has proved that women can do what men cannot do. Chipko movement is a vivid example of this.

Man's need for food, water, housing and other things depends on the environment around us. A balanced natural cycle exists between environment and humans, plants and animals. Human society is playing an important role in polluting the natural environment, in turn it is also negatively affecting life on the planet.

First of all, humans should share living space with other animal species in the environment on which they live with mutual dependence.

It is our responsibility to save our environment and the earth and to create healthy and happy life prospects here. World Environment Day is observed all over the world on June 5 to protect the environment and to keep the whole world free from pollution. The main purpose of this day is that as a citizen of our country, it is our responsibility to clean the earth from pollution and pollution. Make free

Therefore, I urge everyone to plant a plant as much as possible and participate in protecting the environment in keeping the natural beautiful.

"Nature can fulfill man's need, not his greed."

"Take care of environment only then country will become great"

\section{REFERENCE LIST}

1. Aggarwal G.K. "Social Research and Statistics", Sahitya Bhavan Publication Agra Aggarwi

Agrawal G.K. "Rural Sociology “, Sahitya Bhavan Publication Agra 2001

Aggarwal G.K. "Indian social system and social change", Agra Bus Stop Agra 1986 Atal Yogesh " 25 years of Indian family".

BR Ambedkar Who Are The Shudraj Mumbai 1970

Kumar Anand, "The Dynamics of Contemporary Indian Society", Vivek Prakashan New Delhi 190

Ketkar, BS History of Cast in India Ithakar, New York, 1908 